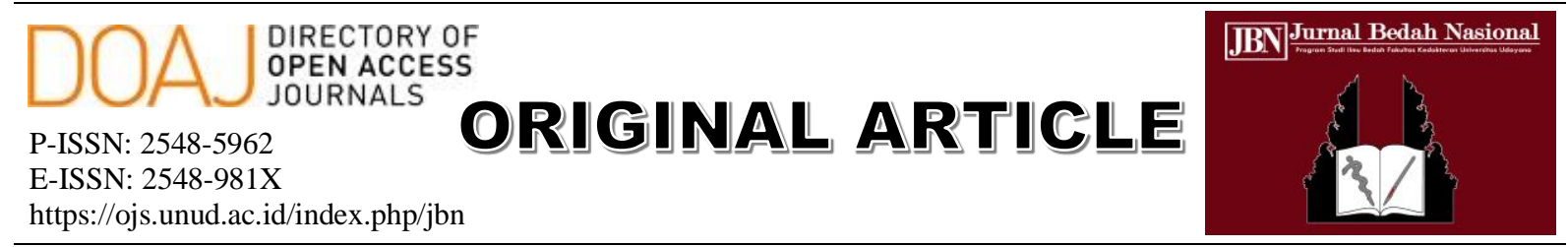

\title{
Characteristic of Patients with Gastric Perforation due to Peptic Ulcer in Dr. Soetomo General Hospital Surabaya in the Period of January - December 2016
}

\author{
Esthiningrum Dewi Agustin ${ }^{1 *}$, Mamiek Dwi Putro², Herry Purbayu ${ }^{3}$ \\ ${ }^{1}$ Faculty of Medicine, Airlangga University/Dr.Soetomo Hospital, Surabaya. \\ ${ }^{2}$ Digestive Surgery Division, Faculty of Medicine, Airlangga University/Dr.Soetomo Hospital, Surabaya. \\ ${ }^{3}$ Gastroenterology and Hepatology Division, Faculty of Medicine, Airlangga University/Dr.Soetomo Hospital, \\ Surabaya. \\ *Corresponding author: esthiagustin@ hotmail.com.
}

\begin{abstract}
Aim: This study aims to study the profile of patients with gastric perforation caused by peptic ulcer. Method: This is a retrospective study by obtaining patients data from medical records in the Medical Record Centre of Dr. Soetomo General Hospital during the period of January - December 2016 and analyzed descriptively. Result: 66 patients were identified (45 male and 21 female), most of them were between age 60 - 69 years old, and live in Surabaya (45.45\%). 30.3\% of patients No malignancy was found during the anatomic-pathological examination. 30.3\% of patients have a long term NSAID taking, while $53.03 \%$ of patients came with a habit of traditional medicine consumption. Perforations were mostly located $1-5 \mathrm{~cm}$ pre-pyloric and between the range $0.5-1 \mathrm{~cm}$ in diameter $(56.6 \%$ and $69.7 \%$, respectively). Conclusion: With the lack of information, it still needs further studies with more completed data for better accuracy.
\end{abstract}

Keywords: gastric perforation, peptic ulcer, Surabaya.

DOI: https://doi.org/10.24843/JBN.2019.v03.i02.p04

\section{INTRODUCTION}

A peptic ulcer is one of the serious digestive tract problems in the world. Based on 2014 World Life Expectancy, the mortality rate of peptic ulcer in Indonesia reaches $0.8 \% .^{1}$ If a peptic ulcer were not appropriately treated, gastric perforation could be one of the complications that occur. Peptic ulcer arises due to an imbalance of aggressive and defensive factors of the mucosa. ${ }^{2}$ Defensive factors consist of bicarbonate, blood flow, mucus, cell junction, and apical resistance, while aggressive factors consist of stomach acid, pepsin, Helicobacter pylori, and NSAIDs (nonsteroidal anti-inflammatory drugs). ${ }^{2}$

Helicobacter pylori and consumption of NSAIDs are the main risk factors. As a developing country, Helicobacter pylori infection is thought to be still quite common.
On the other hand, what is still prevalent in the community is the consumption of NSAIDs and herbs as pain relievers. As a complication, gastric perforation is an abdominal emergency that requires immediate treatment. There is also a possibility for perioperative complications that increase mortality. So far, few researches in Indonesia conveys the characteristics of patients with gastric perforation. This study was conducted to provide an overview of patient demographics, NSAID and herbs consumption habits, and the location and size of perforations in the majority of patients. None study has been done in Dr. Soetomo General Hospital and by doing this research, we hopefully will be able to figure out the most common cause of gastric perforation in the community, so that people can recognize and manage to prevent it. 


\section{METHODS}

This research was a non-experimental study with a retrospectively descriptive design. The researcher recorded patient data from medical records as secondary data in the Medical Record Center of the Dr. Soetomo General Hospital and has previously been declared ethically. The medical records recorded were all medical records of patients with gastric perforations due to a peptic ulcer at Dr. Soetomo in the period January December 2016 with a total sampling technique. Patients who come with generalized peritonitis are the inclusion criteria of this study.

Data taken from this study are patient demographics, history of consumption of NSAIDs and herbs, histopathological examination results, and description of the location and size of gastric perforations. The patient's demographics were taken from the patient's data sheet, the history of NSAID consumption and herbal medicine was taken from the history sheet. All of them were listed in the medical record. Anatomical Pathology Examination was carried out in the Anatomical Pathology Installation of Dr. Soetomo. The tissue specimens were taken during surgery. All data were analyzed descriptively and displayed in graphs and tables. Descriptions of charts and tables are arranged in narrative form.

\section{RESULTS}

Based on the medical record of patients with a peptic ulcer who had gastric perforation at Dr. Soetomo General Hospital Surabaya period January-December 2016, overall there were 66 patients. Data collected for this study are patient demographics, history of NSAID consumption and herbal medicine, results of anatomical histopathology examination, and location and size of gastric perforation.
The majority of patients were recorded as male (68.18\%) and in the age range of 60-69 years $(36.36 \%)$. Meanwhile, most patients were from Surabaya, East Java, Indonesia (Table 1).

Table 1. Patients Demography

\begin{tabular}{lcc}
\hline Characteristic & n & \% \\
\hline Sex & & \\
Male & 45 & 68.18 \\
Female & 21 & 31.82 \\
Age (years old) & & \\
$<40$ & 3 & 4.55 \\
$40-49$ & 3 & 4.55 \\
$50-59$ & 21 & 31.82 \\
$60-69$ & 24 & 36.36 \\
$70-79$ & 13 & 19.7 \\
$80-89$ & 2 & 3.03 \\
Domicile & & \\
Bangkalan & 7 & 10.61 \\
Gresik & 5 & 7.58 \\
Jember & 1 & 1.52 \\
Jombang & 1 & 1.52 \\
Mojokerto & 3 & 4.55 \\
Pasuruan & 1 & 1.52 \\
Sampang & 2 & 3.03 \\
Sidoarjo & 9 & 13.64 \\
Surabaya & 30 & 45.45 \\
Tuban & 7 & 10.61 \\
\hline
\end{tabular}

According to history, $30.3 \%$ of patients with a history of long-term NSAID consumption were obtained (Table 2). In addition, a total of $53.03 \%$ is obtained with a history of consumption of traditional herbal medicine (Table 3). Also, some patients $(6.06 \%)$ had a history of consumption of other drugs, such as vitamins, antacids, and corticosteroids.

Table 2. History of NSAID consumption

\begin{tabular}{lccc}
\hline NSAID & $\begin{array}{c}\text { Male } \\
(\mathbf{\%})\end{array}$ & $\begin{array}{c}\text { Female } \\
(\mathbf{\%})\end{array}$ & $\begin{array}{c}\text { Total } \\
(\mathbf{\%})\end{array}$ \\
\hline Yes & $9(20)$ & $11(52.38)$ & $20(30.3)$ \\
No & $24(53.33)$ & $4(19.05)$ & $28(42.42)$ \\
Others & $2(4.44)$ & $2(9.52)$ & $4(6.06)$ \\
No data & $10(22.22)$ & $4(19.05)$ & $14(21.21)$ \\
\hline
\end{tabular}

NSAID: nonsteroidal anti-inflammatory drugs 
Table 3. History of traditional herbs consumption

\begin{tabular}{lccc}
\hline $\begin{array}{c}\text { Traditional } \\
\text { herbs }\end{array}$ & $\begin{array}{c}\text { Male } \\
(\boldsymbol{\%})\end{array}$ & $\begin{array}{c}\text { Female } \\
(\boldsymbol{\%})\end{array}$ & $\begin{array}{c}\text { Total } \\
(\boldsymbol{\%})\end{array}$ \\
\hline Yes & $25(55.55)$ & $10(47.62)$ & $35(53.03)$ \\
No & $9(20)$ & $7(33.33)$ & $16(24.24)$ \\
No data & $11(24.44)$ & $4(19.05)$ & $15(22.72)$ \\
\hline
\end{tabular}

Anatomical histopathology in specimens taken during laparotomy aims to identify certain inflammatory processes and exclude malignancy. In this study, no malignant specimens were found (Table 4).

Table 4. Histopathological examination

\begin{tabular}{lccc}
\hline Histopathology & $\begin{array}{c}\text { Male } \\
(\mathbf{\%})\end{array}$ & $\begin{array}{c}\text { Female } \\
(\mathbf{\%})\end{array}$ & $\begin{array}{c}\text { Total } \\
(\mathbf{\%})\end{array}$ \\
\hline $\begin{array}{l}\text { Chronic } \\
\text { inflammation }\end{array}$ & $30(66.66)$ & $16(76.19)$ & $46(100)$ \\
No data & $15(32.61)$ & $5(25)$ & $20(30.3)$ \\
\hline
\end{tabular}

Based on the results of the surgery report, the location and diameter of the gastric perforation have been described. The location of the perforation is explained by referring to the pre-pylorus in centimeters, as well as the diameter of the perforation (Table 5). Perforations were located at $1-5 \mathrm{~cm}$ prepylorus and $0.5-1 \mathrm{~cm}$ in diameter in the majority of patients with an average of 2.84 $\mathrm{cm}$ pre-pylorus and $1.33 \mathrm{~cm}$ in diameter (Table 6).

Table 5. Location of pre-pylorus perforation

\begin{tabular}{cccc}
\hline $\begin{array}{c}\text { Site of } \\
\text { Perforation }\end{array}$ & $\begin{array}{c}\text { Male } \\
(\boldsymbol{\%})\end{array}$ & $\begin{array}{c}\text { Female } \\
(\boldsymbol{\%})\end{array}$ & $\begin{array}{c}\text { Total } \\
(\boldsymbol{\%})\end{array}$ \\
\hline$<1 \mathrm{~cm}$ & $1(2.22)$ & $0(0)$ & $1(1.51)$ \\
$1-5 \mathrm{~cm}$ & $35(77.77)$ & $15(71.43)$ & $50(75.76)$ \\
$>5 \mathrm{~cm}$ & $2(4.44)$ & $1(4.76)$ & $3(4.54)$ \\
No data & $7(15.55)$ & $5(23.81)$ & $12(18.18)$ \\
\hline
\end{tabular}

Table 6. Diameter of perforation

\begin{tabular}{cccc}
\hline Diameter & $\begin{array}{c}\text { Male } \\
(\boldsymbol{\%})\end{array}$ & $\begin{array}{c}\text { Female } \\
(\boldsymbol{\%})\end{array}$ & $\begin{array}{c}\text { Total } \\
(\boldsymbol{\%})\end{array}$ \\
\hline$<0.5 \mathrm{~cm}$ & $2(4.44)$ & $0(0)$ & $2(3.03)$ \\
$0.5-1 \mathrm{~cm}$ & $22(48.88)$ & $14(66.66)$ & $36(54.54)$ \\
$>1 \mathrm{~cm}$ & $17(37.77)$ & $5(23.81)$ & $22(33.33)$ \\
No data & $4(8.88)$ & $2(9.52)$ & $6(9.09)$ \\
\hline
\end{tabular}

\section{DISCUSSION}

Based on medical records, the highest number of patients is in the age range of 6069 years old. This is different from what was revealed by previous studies that patients with an earlier age range of the $4^{\text {th }}-5^{\text {th }}$ decade experience peptic ulcer disease. In the other side, it is supported by other previous studies that the average age of patients with gastric perforation is 60 years old. ${ }^{3}$

In this case, age is an important factor in determining mortality and morbidity. Meanwhile, based on sex, $68.18 \%$ of patients were male, and $31.82 \%$ of patients were female, which if stated in a comparison of 2.14 and 1 .

This is consistent with what was explained by previous studies, that the ratio of male peptic ulcer patients to women is $2-8$ and 1 . $^{4}$ The result of the study revealed that the domicile of the majority of patients was Surabaya. There are yet no studies that explain further about the domicile of the patient.

One of the triggers for peptic ulcer is prolonged consumption of NSAIDs. Based on medical records, patients were not explicitly asked about the history of NSAID consumption but were asked about a history of consumption of analgesic. Analgesic is thought to be the NSAID group, because it is most commonly used in the community. $30.3 \%$ of patients have a history of long-term consumption of pain reliever. Besides NSAIDs, other drugs that may cause peptic ulcer are steroids, bisphosphonates, immunosuppressant, and cocaine. ${ }^{5}$

There are $6.06 \%$ of patients present with a history of consumption of other types of drugs. Other drugs are vitamins and antacids. There is no further explanation about what vitamins are consumed. Antacid use is estimated due to so many complain of gastritis or heartburn before. In addition, 
patients were also asked about traditional herb consumption. Actually, the habit of consuming herbs in the community is still high. Based on medical record data, the herbs that are often consumed are herbal antirheumatic herbs.

Allegedly the herbal medicine also contained ingredients that function as analgesics, which may be the same as the NSAID drug class, so it can also increase the risk of ulcers in the stomach. There are $53.03 \%$ of patients come with a long history of consumption of herbal medicine. All specimens taken during surgery do not show malignancy but chronic inflammation. This inflammation can be caused by Helicobacter pylori infection that causes the production of inflammatory mediators and IL-8. ${ }^{3}$ As with NSAIDs, disruption of the balance of the lining of the gastric mucosa occurs in several ways; decreased mucus production as a factor in gastric protection, disruption of gastric acid production, and inhibition of COX-1, which causes vasoconstriction so that vascularity is not optimal which can cause necrosis of epithelial cells. ${ }^{6}$

Meanwhile, based on surgery reports, the perforations are mostly located in $1-5 \mathrm{~cm}$ prepylorus. According to its anatomical location, the stomach is divided into several parts, ranging from cardia, fundus, corpus, antrum, and pylorus. The pre-pyloric area can be assumed to be antrum. The same intention was expressed by Leeman's study that gastric perforation is located mostly on the distal third of the stomach. ${ }^{4}$

Besides the location of the perforation, also observed the diameter of the perforation. $56.06 \%$ of patients underwent laparotomy due to perforations with a diameter of $0.5-1$ $\mathrm{cm}$. The same was reported by Madiba et al. that the most perforated size of their patients is $<1 \mathrm{~cm} .{ }^{7}$ The diameter of perforation needs to be reviewed because it also affects the patient's morbidity and mortality. ${ }^{8}$

\section{CONCLUSION}

There were 66 patients with gastric perforation due to peptic ulcer at Dr. Soetomo Surabaya and most of them are male (68.18\%), aged between 60-69 years and are from Surabaya. 30.3\% have a history of longterm NSAID consumption and $53.03 \%$ with a history of consumption of traditional herbal medicine. The overall results of the histopathological examination did not show any malignancy. Meanwhile, based on surgery reports, gastric perforation was mostly found in $1-5 \mathrm{~cm}$ pre-pylorus (75.76\%), with diameters in the range 0.5-1 $\mathrm{cm}(54.54 \%)$.

\section{ACKNOWLEDGEMENT}

We would like to thank Dr. Mamiek and Dr. Herry for the kind guidance and comments that greatly improved the manuscript. We would also like to show our gratitude to Surgery Department medical staffs that considerately help us during the data collecting process although any errors are our own and should not tarnish the reputation of these esteemed persons.

\section{DISCLOSURE}

Authors declare no conflict of interest of this report.

\section{REFERENCES}

1. World Life Expectancy. World Life Expectancy. [serial online] 2014 [cited 2017 Sep 5]. Available from: http://www.worldlifeexpectancy.com/

2. Brunicardi FC, Andersen DK, Biliar TR, et al. Schwartzs Principles of Surgery, $10^{\text {th }}$ Edition. New York: McGraw Hill Education; 2015. 
3. Leeman MF, Skouras C, Paterson-brown $\mathrm{S}$. The management of perforated gastric ulcers. Int J Surg. 2013;11:322-4.

4. Taş İ, Ulger BV, Önder A, et al. Risk 7. Madiba TE, Nair R, Mulaudzi TV, et al. factors influencing morbidity and mortality in perforated peptic ulcer disease. Ulus Cerrahi Derg. 2014;31:205.

5. Stewart DJ, Ackroyd R. Peptic ulcers and their complications. Surgery. 2011;29:568-74.

6. Koto K., Asrul, Muradi A. Characteristic of gastric perforation type and the histopathology at Haji Adam Malik general hospital Medan-Indonesia. Bali Med J. 2016;5:166-8.

Perforated gastric ulcer - reappraisal of surgical options. $S$ Afr $J$ Surg. 2005;43:58-60.

8. Đorđević I, Zlatić A, Janković I. Treatment of Perforative Peptic Ulcer. Scientific Journal of the Faculty of Medicine in Nis. 2011;28:95-107. 